\title{
NATURE AND CLASSIFICATION ASPECTS OF LOCAL BUDGET REVENUES
}

\author{
Oksana VINNYTSKA ${ }^{1}$, \\ National Academy of Statistics, Accounting and Audit, Ukraine
}

\begin{abstract}
The purpose of the article is to determine the essential characteristics of local budgets and justify their classification aspects. Methodology. In the course of writing used general scientific and special methods of knowledge: dialectical and systemic-functional - to summarize the theoretical concepts of income of local budgets; analysis and synthesis - to detail the subject of research and study its components; logic synthesis - to justify approaches and proposals for the formulation of local budgets. Results. Proved that today there is no single view on the interpretation of economic categories "revenues of local budgets." A refined concept of "local budget revenues" from the standpoint of material content, form, organizational structure and nature of local budgets. Local budget revenues determined as part of the financial resources of society, which is accumulated by local authorities to enforce their tasks and functions to implement current and future challenges of social infrastructure in the regions. Proved that the revenues of local budgets are derived from their own, and assigned to the established order of state taxes, fees and other mandatory payments. The main feature of their own revenues is the direct subordination of local government. The main feature is the fixed income long-term nature of their attachment to the appropriate budget. Value/originality. Proved that the presence in the economic literature of different classification criteria of local budget on various grounds provides multi classification that reflects all the features of the formation, use and functional differences revenues of local budgets. This approach provides the basis for improving the functioning of the theoretical foundations of the budget process in Ukraine at the level of local authorities.
\end{abstract}

Key words: fiscal policy, government revenues, budget revenues, revenues of local budgets, tax revenues, types of income, classification of incomes.

JEL Classification: E62, E64, E63

\section{Introduction}

Studies of the revenue of local budgets Ukraine is of particular relevance, especially because it is local governments characterize the level of economic development, arid through the proper implementation of the budgetary process ensure economic and social stability and adequate standard of living.

Strengthening financial, budgetary systems in the context of European integration processes require a rethinking of social and economic nature and the place and role of the budget in the economic system of the state, the theoretical study of the formation of the revenue base and use of proceeds budgets nature of the budget and its importance in creating an effective system of intergovernmental relations and territorial financial equalization. In view of this exceptional urgency acquire theoretical, methodological and applied research questions the role and importance of the budget, its adaptation to the requirements of market economic environment.

In conditions of deepening disparities in development of different regions of Ukraine revenues are problems in the circle of interests of research scientists, practitioners and the public. So a priority in the financial science. The need to address these problems causes relevance of the chosen research topic.

\section{Analysis of recent research and publications}

Introduction of scientific publications made it possible to estimate the theoretical and practical level of development problems of formation of revenues of local budgets Ukraine. An important contribution to research features of formation of local budgets made by such scholars as Bondaruk T.G., A.P. Kirilenko, Yury S. and others. Most sources, special attention is paid to the theoretical aspects of the nature and structure of local revenues and underestimated the role of fiscal adjustment.

This study aims to determine the essential characteristics of local budgets and justify their classification aspects.

In the course of writing used general scientific and special methods of knowledge: dialectical and systemicfunctional - to summarize the theoretical concepts of income of local budgets; analysis and synthesis - to detail

\footnotetext{
Corresponding author:

${ }^{1}$ Department of Finance, National Academy of Statistics, Accounting and Audit.

E-mail: chutka.oksana@mail.ru
} 
the subject of research and study its components; logic synthesis - to justify approaches and proposals for the formulation of local budgets.

\section{The main material. Research essence revenue}

Exploring the nature of budget revenues, to distinguish between the definition of "public revenue" and "budget revenue”, which are components of conceptual apparatus of financial science. Revenues - an economic (financial) category, objective phenomenon, and budget revenues financial concepts are associated with the activities of the state, subjective actions of people. Revenues - broader definition than budget revenues (Fedosov, Yurii, 2012). They include both budget revenues and net income of state enterprises.

Revenues cover the part of financial relations, which is associated with the formation of financial resources at the disposal of the state and state enterprises. This accumulated financial resources of the state belong to the central (concentrated in the state budget funds and purpose), and those that remain at the disposal of state-owned enterprises is decentralized (Venger, 2009; Romanenko, Ogorodnyk, 2003).

Overall, budget revenues are treated as a collection of local revenues on the irrevocable basis, charged under the laws of Ukraine.

Thus, the concept of budget revenues is a narrower concept of public revenues. It should also be borne in mind that some of the financial resources available to the state comes out of the budget, with other financial institutions, such as public credit, public insurance, etc. (Tripak, 2011). Thus, budget revenues are defined as revenues for the main national fund required for the smooth development of all sectors to improve welfare and cultural level of the people, defense, maintenance of public bodies and local authorities.

Exploring the notion of retrospective incomes of local budgets, we note that to the 19th century, term revenues of local budgets has not been used and the revenue of local government with central government revenues were interpreted as state or public.

In his fundamental work "The Wealth of Nations. The study of the nature and cause of the welfare of nations "(1776) Adam Smith first expressed feasibility of delimitation of state and local budgets and, therefore, their income (A. Smith, 1776). He stressed that in addition to public financial management, there is also the local financial sector, highlighting the types of income such as non-tax (income from capital, enterprises, state assets) and taxes.

In Soviet times the revenues of budgets categories examined by such scientists as N.Rovenskyi and D. Butakov. The scientist N. Rovenskyi in 1944 (Lehkostup, 2010;Rovenskyi, 1944) indicates the proper use of revenues, income and grouping on the basis of the recovery, it distinguishes between tax revenues and revenues arising economic activities of local authorities.
The category of revenues of local budgets and consider as a set of economic relations that contribute to the territorial distribution of gross domestic product (GDP) of the state and ensure the development of financial base of local authorities (Lehkostup, 2010).

The biggest question of the nature and formation of local budgets in the financial science is acquired at the time of independence of Ukraine. Development of conceptual bases of local budgets in this time closely associated with the recognition of local government and the expansion of financial independence of heal authorities. However, many researchers do not distinguish the concept of focal budgets, giving the definition of budget revenues as a whole, both at national and local levels.

Under budget revenues authors of "Budget system of Ukraine” S.l. Yurii and J. M. Beskyd (Yurii, Beskyd, 2000) to understand the state of centralized resources that are necessary for the performance of the functions, the main activities of the state, due to the goals and objectives that characterize its essence. Such revenues express the economic relations arising in the process of formation of funds of funds and at the disposal of the government and management (S.V.Savchuk, 2012). In this definition reveals valuable, distribution character concept, but not set specific local budget revenues.

V.V. Asauf, A.V .Dementiev budget revenues interpreted as funds received under the legislation available to the appropriate level of government (Asaul, Dementiev, 2010). Budget revenues are divided into tax and non-tax sources and gratuitous transfer. In the current year budget revenue is credited as the balance that formed at the end of the previous year.

O.R. Romanenko in the manual "Finance" (Romanenko, 2004) revealed the economic nature of this concept. The national budget revenues scientist calls the economic relations arising from state entities and individuals in the formation of the country's budget.

However, scholars such as V.D. Bazylevych, O.D. Vasylyk, O.P. Kyrylenko, U.V. Pasichnyk, V.V. Pysmennyi, S.I. Yurii delimiting the notion of state and local budgets.

V. Literate (Literate, 2012) defines the revenues of focal budgets as part of the financial resources of local authorities with which to create a financial base to meet socîal needs. Manifestations of relations arising in the process of lotai budget revenues are the revenues of various kinds, and the material and the material embodiment - cash funds raised in the capital budget and used for the intended purpose.

Professor U.V. Pasichnyk (Pasichnyk, 2008) focuses on identifying the economic substance of revenues, considered as a separate economic category expressing the scope of economic relations of society, which is associated with the formation, distribution and use financial resources of regional and local governments used to provide current and future challenges of the region.

Professor O.P. Kyrylenko considers local budget revenues as revenues, consisting of equity and fixed 
income, which is defined for the long term, which should create the necessary conditions for the implementation of strategic planning (Kyrylenko, 2004). The scientist stressed that own revenue receipts not included in the calculation of intergovernmental transfers to local budgets. As a result, this procedure provides a direct interest of local governments in increasing the revenue side.

Professor S, George shared revenues of local budgets are fixed and control (Yurii, 2003). From the standpoint of the scientist, considered as fixed income, which by law is fully reserved for certain budget and not be transferred to lowerlevel budgets or partially fixed budgets higher level and to a certain extent be transferred to the budgets of lower level. However, the budget revenues is based not only on the fixed revenue sources. A separate administrative-territorial units assigned revenue sources may not suffice to cover the costs of the program of economic and social development. In such cases the regulatory returns. The above income characterized in that transmitted in the form of deductions from state taxes and fees from the budget to the budgets of higher level to lower level of rebalancing.

V.D. Bazylevych stresses that local budget revenues are derived from its own sources and assigned national taxes, fees and other mandatory payments (Bazylevych, 2002).

K.M. Vladimirov, N.H. Chuiko and O.F. Rogalskyi (Vladimirov, Chuiko, Rogalskyi, 2007) noted only that the revenues of local budgets is the financial basis of local government and the state is actively involved in the formation of revenues of local budgets, financially support it. They, like most authors, immediately begin to disclose the composition of local budgets and sources of their formation, not focusing on the concept.

O.D. Vasylyk and K.V. Pavliuk (Vasylyk, Pavliuk, 2004) believe that the economic substance of local budgets manifested in the formation of funds which are financial support of local councils and local government administration, and use these funds to finance the maintenance and development of social infrastructure, local economy and more.

Thus, the study of scientific papers on the problems of formation of local budgets give reason to formulate their own definition of "local budget revenues" - a combination of monetary and economic relations of society to ensure the formation, distribution of financial resources at the regional level and optimal, efficient regional development with decentralized management in the face of local authorities.

That is, the incomes of local budgets - are financial resources of local authorities, which are used for the development of a particular region and which should meet the scope of authority established by law.

\section{Classification aspects revenues and expenditures of local budgets}

The study of literature (Bondaruk, 2013) suggests that aspects of the issue of classification of revenues and expenditures of local budgets is quite controversial, because each of scholars considers and distinguishes between types of classifications of income and expenditure from different perspectives. In that reason, there is no one universal classification of revenues and expenditures of the local budget.

Classification Analysis of local budgets in the current conditions is of particular relevance. The scientific literature presents various criteria for the classification of local budgets, indicating that the multifaceted problems of coverage sources of local revenues and functional areas

Table

Multi classification of local budget revenues

\begin{tabular}{|c|c|}
\hline $\begin{array}{l}\text { The criteria for } \\
\text { classification }\end{array}$ & Items of income \\
\hline $\begin{array}{l}\text { According } \\
\text { to the Budget Code }\end{array}$ & $\begin{array}{l}\text { - Own; } \\
\text { - Mounted. }\end{array}$ \\
\hline $\begin{array}{l}\text { By section according } \\
\text { to budget classification }\end{array}$ & $\begin{array}{l}\text { - Tax revenues (taxes, fees and } \\
\text { charges); } \\
\text { - Non-tax revenues (revenues from } \\
\text { property and business activity, revenues } \\
\text { from fines, etc.) } \\
\text { - Revenues from capital transactions } \\
\text { (cash flow from the sale of ownerless } \\
\text { property, property that the law passed } \\
\text { heir to the state, and treasures) } \\
\text { - Official transfers (subventions, } \\
\text { grants, subsidies) }\end{array}$ \\
\hline For localization & $\begin{array}{l}\text { - Territorial income received in the } \\
\text { territory of local government } \\
\text { - Income derived in other areas }\end{array}$ \\
\hline $\begin{array}{l}\text { For socio-economic } \\
\text { content }\end{array}$ & $\begin{array}{l}\text { - revenues from public entities, } \\
\text { municipal, private, collective } \\
\text { ownership; } \\
\text { - funds received from the public }\end{array}$ \\
\hline $\begin{array}{l}\text { Under the terms of } \\
\text { repayment }\end{array}$ & $\begin{array}{l}\text { - Inverse income - placing local loans } \\
\text { - Irreversible revenues - payments } \\
\text { and payments of businesses and } \\
\text { individuals }\end{array}$ \\
\hline $\begin{array}{l}\text { The level of } \\
\text { centralization }\end{array}$ & $\begin{array}{l}\text { - Decentralized - revenue used at the } \\
\text { place of education } \\
\text { - Centralized - revenues that are } \\
\text { concentrated in the state budget and } \\
\text { other target funds centralized cash }\end{array}$ \\
\hline By means of attracting & $\begin{array}{l}\text { - Taxes } \\
\text { - Fees } \\
\text { - Mandatory Payments } \\
\text { - Other revenues }\end{array}$ \\
\hline $\begin{array}{l}\text { By the method of } \\
\text { mobilization }\end{array}$ & $\begin{array}{l}\text { - Mandatory } \\
\text { - Voluntary }\end{array}$ \\
\hline $\begin{array}{l}\text { The frequency of } \\
\text { occurrence }\end{array}$ & $\begin{array}{l}\text { - Ordinary - regularly included in } \\
\text { income } \\
\text { - Emergency - included in income on } \\
\text { exceptional but justified circumstances }\end{array}$ \\
\hline $\begin{array}{l}\text { According to sources } \\
\text { of formation and use of } \\
\text { the form }\end{array}$ & $\begin{array}{l}\text { - Income from property } \\
\text { - } \quad \text { Revenues of local budgets, which are } \\
\text { a source of revenue, cost } \\
\text { - The sale of land } \\
\text { - Different types of payments }\end{array}$ \\
\hline By way of enrollment & $\begin{array}{l}-\quad \text { Income of the general fund } \\
-\quad \text { Special Fund revenues }\end{array}$ \\
\hline
\end{tabular}


of use. Multi classification of local budget revenues in the table.

According to the code of budget classification, budget revenues are distributed in the following sections: tax revenues, non-tax revenues, revenues from capital transactions and transfers. Depending on the location of the territorial local revenues advisable to separate: income received in the territory of local government, and the income derived in other areas, which are directed at a particular local budget.

In the classification of income socioeconomic taken into account the existence of different forms of ownership. The most commonly used classification division revenues for tax and non-tax. Also, budget revenues can be both mandatory and voluntary revenue.

Based on the sources of division formation, laid criterion, thereby be obtained revenues: income, personal income, other budgets funds and others.

Some authors share income on ordinary and extraordinary (Momot, 2012). Also, revenues are allocated general and special funds of the local budget.

That is, there are different criteria for the classification of local budgets. The following multicriterial classification of local budget is characterized by complexity, logic and allows for more in-depth and comprehensive analysis of the composition and sources of income of local budgets.

\section{Conclusions}

In the context of the above study the nature and classification aspects of local budgets Ukraine makes it possible to reach such conclusions.

Today there is no single view on the interpretation of economic categories "revenues of local budgets." A refined concept of "local budget revenues" from the standpoint of material content, form, organizational structure and nature of local budgets. Local budget revenues determined as part of the financial resources of society, which is accumulated by local authorities to enforce their tasks and functions to implement current and future challenges of social infrastructure in the regions.

It is proved that the revenues of local budgets are derived from their own, and assigned to the established order of state taxes, fees and other mandatory payments. The main feature of their own revenues is the direct subordination of local government. The main feature is the fixed income of longterm nature of their attachment to the appropriate budget.

The presence in the economic literature of different classification criteria of local budget on various grounds provides multi classification that reflects all the features of the formation, use and functional differences revenues of local budgets. This approach provides the basis for improving the functioning of the theoretical foundations of the budget process in Ukraine at the level of local authorities.

\section{References}

Asaul V., Dementev A. \& Molchanov D. (2010). Finance, credit and money. - Appeal : Textbook. Allowance. - 322 p. Bazylevych V. \& Balastryk L. (2002), Public finances : teach. Manual. Society. - Atika. - 368 p.

Bondaruk T.G. (2013) Economic and statistical analysis of formation of local budgets. Statistics, № 4, p. 7-15.

Fedosova B. \& Yuriia S. (2012) The budget system: Textbook under sciences. Ed. Publication. - K. Ternopil: TSUL-economic thought. $-871 \mathrm{p}$.

Kirilenko A. (2004). Local Finance: Textbook. - Ternopol: Acton. - 140 p.

Legkostup I. (2010). Features of local budgets Ukraine and ways to strengthen their revenue base. Formation of market relations in Ukraine, № 3, p. 165-170.

Literate V. (2012). Local Finance: teach. Guidances. - Ternopol: Economic thought TNEU. - 200 p.

Momot A.O. (2012), Methodological approaches to classification of local budget. Development Management, № 8, p. 125-126.

Pasichnyk Y.V. (2008) Budget system of Ukraine. Textbook. 2nd ed., Revised. and add. - K. Knowledge. - 670 p.

Romanenko O.R. (2004) Finance. - K.: Centre textbooks. -312 p.

Romanenko O., Ohorodnyk, Ziaziun S. \& Slavkova A. (2013). Finance: Teach method, to self. Explore, discipline. 2nd ed., Revised, and add. KNEU, 387 p.

Rovinskii N.N (1944). USSR state budget. Textbook for financial and economic institutions. - M.: Gosfinizdat. 385 p. [Electronic resource]. - Retrieved from: http://istmat.info/node/39283

Savchuk S. (2012) The oretical and conceptual foundations defining revenue as the object budgeting. Science and Economics. №1(25), p. 81-89.

Smith A. (1776) Wealth of Nations. The study of the nature and cause of the welfare of nations. [Electronic resource]. - Retrieved from: http://www.kbuapa.kharkov.ua/e-book/tpdu/13

Tripak M. Revenues of local budgets Ukraine : pragmatic and fiscal regulation / [Electronic resource]. Retrieved from: http://library.tneu.edu.ua/index.php/nmkd/64-resursy-biblioteky/pratsi-vykladachivtneu/t/94-2011-09-05-09-52-41

Vasiliko O. \& Pavlyuk K. (2004). The budget system of Ukraine: the textbook. - K.: Centre teach. years. - 544 p. Venher V.V. (2009) Finance: teach. Ref. for students. HI. teach, bookmark. - KCenter of educational literature. - 432 p. Vladimirov K.M., Chuiko N. \& Rogalskyy A. (2007) Local Finance [Text] : Tutorial. - Kherson: Oldie-plus. - 352 p. Yurii S. \& Beskyd J. (2000). The budget system of Ukraine: Training, guidances, for the studio. Econ. spec. HI. teach, bookmark. - K.: NIOS. -400 p.

Yuri S., Ivanuh R. \& Dusanovskyy S. (2003) Economic and social aspects of economic complex of Ukraine : Monograph. - Ternopol: Zbruch. - 468 p. 


\section{Оксана ВИННИЦКАЯ}

\section{СУЩНОСТЬ И КЛАССИФИКАЦИОННЫЕ АСПЕКТЫ ДОХОДОВ МЕСТНЫХ БЮДЖЕТОВ}

Аннотация. Целью статьи является определение сущностных характеристик доходов местных бюджетов и обоснование их классификационных аспектов. Методы исследования. В ходе написания статьи использованы общенаучные и специальные методы исследования:диалектический и системно-функциональный-для обобщения теоретических концепций формирования доходов местных бюджетов; анализа и синтеза - для детализации предмета исследования и изучения его составляющих; логического обобщения - для обоснования подходов и предложений относительно формулировки доходов местных бюджетов. Результаты. Обосновано, что на сегодняшний день не существует единого мнения о трактовке экономической категории «доходы местных бюджетов». Предложено толкование понятия «доходы местных бюджетов» с позиций материального содержания, формы, организационной структуры и характера местных бюджетов. Доходы местных бюджетов определены как часть финансовых ресурсов общества, которые аккумулируются местными органами власти для обеспечения выполнения возложенных на них задач и функций с целью реализации текущих и перспективных задач развития социальной инфраструктуры регионов. Обосновано, что доходы местных бюджетов формируются за счет собственных и закрепленных в установленном порядке общегосударственных налогов, сборов и других обязательных платежей. Главным признаком собственных доходов является непосредственная их подчиненность местному самоуправлению. Главный признак закрепленных доходов заключается в долгосрочном характере их закрепление за соответствующим бюджетом. Значение. Обосновано, что наличие в экономической литературе разных критериев классификации доходов местных бюджетов по различным признакам обеспечивает многокритериальную их классификацию, отражает все особенности формирования, использования и функциональные различия доходов местных бюджетов. Такой подход создает базу для совершенствования теоретических основ функционирования бюджетного процесса в Украине на уровне местных органов власти. 